\title{
Leadership in Recreation for Special Populations in the 21st Century 甘一世紀特殊康樂的領導地位
}

\author{
Dr. Dicken Yung \\ Professor \& Director, Asia Pacific Professional \& Education Programs \\ University of Oregon, USA \\ 容德根博士 (教授/課程主任) \\ 美國俄勒岡大學亞太專業及敉育課程
}

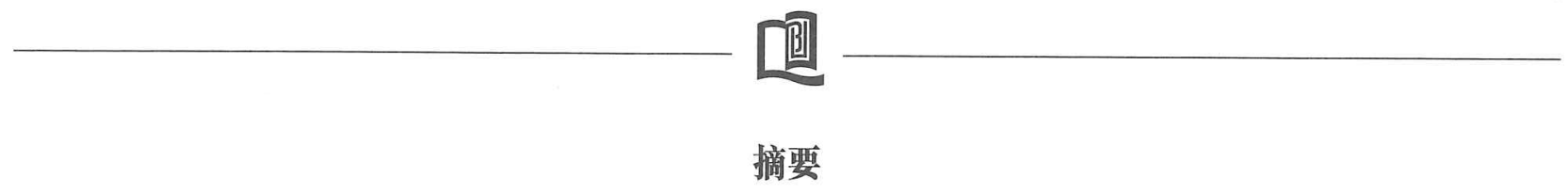

現今社會對傷殘人士的觀點及態度都與廿多年前有很大的改變。本文章試探討特殊康樂在社會上的角色及其領導工作 的必備條件, 讓我們能更有效率地推行特殊康樂活動。而作者從過往累積的經驗, 與讀者分享其要領 : 計有個人興趣及承 諾、認同供求能力、創新意念、服務工作質素、建議、善用體康專業及義務工作者、有效的工作小組、及對政治的機智。

I am honored to be invited by the prestigious Leisure and Recreation Association in Korea to share my thoughts and experiences in connection with leadership in the provision of recreation for special populations i.e. the people with physical or mental disabilities or handicaps and the elderly persons. In the world today there are millions of persons who fall into this category of special populations. So, it is an important issue that we are discussing.

During the last few decades there have been many dynamic developments in the provision of recreation opportunities for persons with handicaps. Community programs and services have expanded. Many new opportunities have developed to meet the ever-increasing leisure needs of these individuals. Public concept of persons with handicapping conditions has improved. I remember quite vividly some 25 years ago in Hong Kong, it was not uncommon that the sight of a person in a wheelchair could attract the attention of many a passers-by. You can imagine the attention a paraplegic athlete playing basketball or swimming in the pool might receive! Today in many communities the picture is totally different! No more will people in the street be alarmed to see people with disabilities even in situations such as sports participation and travel. Developed societies like Korea, USA and others recognize the contributions of recreation to physical, social and psychological health of persons with disabilities. There is no doubt about the burgeoning demand for recreation! (Even back in 1985 the Korea National Tourism Corporation revealed that about $75 \%$ of the 3,973 respondents of a survey on the value of work and leisure considered "leisure is as important as work" (Kim, 1988). Through the continued efforts of public organizations, the community and volunteers, special populations are given many opportunities to enjoy the fun and benefits of leisure activities. As the demand increases, leisure and recreation leaders have to compete with the claims of other disciplines for human and financial resources to meet the leisure needs of those with disabilities.

First, let us begin by focusing on how we as leaders can function more effectively to develop programs for special populations, and how to obtain the resources needed to develop these programs as well as preparing those who will lead these programs.

For more than 25 years I have been personally involved at top levels, both in government and with voluntary agencies, in developing programs for special populations in a variety of locations. I have been a keen advocate for special groups. I would now like to share with you eight characteristics or ingredients that I believe are essential for developing, implementing and administering successful programs. These are:

1. Personal Commitment and Interest

2. Ability to Identify Demands and Needs

3. Creativity and Innovation

4. Quality of Work and Services

5. Advocacy

6. Use of General Recreation Professionals and Volunteers

7. Effective Working Committee/ Board

8. Political Sensitivity/ Awareness and Tactfulness 


\section{Personall Commitment and Interest}

Those who want to develop programs for persons with special needs must themselves be interested in the work, and prepared to work long and hard, and strongly committed to play a leadership role in the process of developing and implementing the program. Likewise, people invited to serve on committees or boards of organizations serving persons with disabilities must also be personally motivated and prepared to work hard and to use their skills and talents to help the organization. We can no longer afford to invite people who just want their names on the committee, and who are not willing to offer any contributions to the organization. The executive committee or board is, in effect, the driving force - the engine that keeps the organization moving. The board is the prime mover that generates results for the benefit of persons with disabilities. There is, of course, another category of positions - honorary positions such as honorary presidents who can sometimes provide immense support and resources of various types such as financial support or important contacts with influential community leaders. Indeed, their role is also very important. They complement the services provided by the hardworking and dedicated executive committees or boards.

Top management of any organization needs to be committed to the practice of effective management skills in order to maximize and to energize the potential of each member. Team-building and teamwork within the agency or groups of volunteers are essential in any successful organization. Develop your skills in relating to people and influencing people to achieve objectives (Mackenzie, 1990). Clearly, these skills are critical in our efforts to generate resources. Naturally, a person reasonably competent in these skills, along with a bit of charisma, often finds it easier to obtain resources.

\section{Ability to Identify Demands and Needs}

By working with informed workers from other related disciplines, recreation professionals can better identify and determine the needs. By involving persons with disabilities in the planning process at the early stage, the chance of having a popular and effective program evolved is much greater. This equally applies to facility planning and curriculum development.

\section{Creativity and Innovation}

We must try to be creative and innovative in our approach to planning and implementing our programs. Innovative projects have at least three distinct values (1) appealing to participants (2) attractive to corporate or individual sponsors, and (3) serving as a stimulus to organizers and voluntary helpers. We must also encourage our co-workers and volunteers to come up with ideas and suggestions for our program so that the activities can become attractive to participants. A creative project often attracts wide publicity and visibility for the agency. It also helps to attract the targeted population to participate in the program. Creativity facilitates the agency to solicit financial support from businesses. Outstanding examples include: The Grocery Scrip project in the US in which a participating chain of stores donates $5 \%$ of the sale to a school every time a supporting customer buys his groceries with the script purchased from the school. "Walk for a million", "Walk for Charity", "Walk for a Dime" in which the "walker" will solicit donations from his sponsor to walk a certain number of miles and the cash obtained will be given to the charity involved. Enormous donations can be obtained this way. "Law Enforcement Torch Run" is a very successful fundraising activity of Special Olympics. Equally successful is the project, Christmas Records of Special Olympics, which involves the donation in kind of songs from accomplished singers. The record alone nets millions of dollars for the organization. "Travel Awards Scheme for Leaders serving persons with handicap" sponsored by a well established travel agent in Hong Kong, involving the donation of about US\$1 Million to cover the expenses on 40 air tickets and 10 day tours in China was another innovative example which impressed the sponsor.

Creative projects of capital works often attract donors. The beautiful PHAB Center (PHAB denotes Physically-handicapped $\&$ Able-bodied), and the popular Cofferdam Water Sports Center in Hong Kong are exemplary. The former was designed to cater to the camping activities of 120 campers with or without disabilities in an effort to promote integration. The project received a substantial donation from the Jockey Club and the granting of a premier land site from the government for the facilities. The water sports center was built with a donation by an owner of a bank, who was impressed with the innovative concept to use the spacious area of sea water within a cofferdam for water sports. The cofferdam was supposed to be restored to nature on completion of a reservoir project but it is now providing a useful leisure service to thousands annually, including persons with disabilities.

Other illustrations include (a) the conversion of a disused military camp into a family recreation camp was also facilitated by a sponsor who was attracted to the innovation idea, and (b) the proposal to use of an under-utilized car-parking building for organized recreation activities for thousands of participants including persons with handicap, received almost instant support from a donor. 


\section{Quality of work and services}

If an agency consistently delivers quality programs and "customer" services to its participants, its activities will generally be well subscribed. This ability to deliver services can have a far-reaching effect: it is a kind of credibility which may become a useful reference to corporate sponsors. One way I have always found useful in getting support from corporate is to invite corporate executives to see your projects and to hear your success stories. Agencies have to ensure that the activities are properly conducted and the staff and volunteers are adequately trained and prepared for the events.

\section{Advocacy}

Advocacy means "one who argues for defends, maintains, or recommends a cause or a proposal." (Kennedy, Smith and Austin, 1991). Basically, it means that in order to promote and sustain a worthy cause or program, agencies should strive to form an opinion of your worthy cause in society by suitably involving the media, businesses or welfare or educational organizations in their promotional efforts and activities. These organizations need to be informed of the mission and the resultant benefits to special populations. That means you have to present and sell your concept the ideas well. Such advocacy deserves our serious professional efforts. The use of supporting research findings and statistical data can be very useful. Most important, you yourself must believe in the concept or the program. With sincerity and enthusiasm you can surely be effective in soliciting finance, and enlisting the assistance of volunteers and the support of the general public.

\section{Use of General Recreation Professionals and Volunteers}

Since it is unlikely to receive increase public funding to support your program, it is important to use the existing staff, and at the same time, enlist the help of volunteers. Stein and Sessoms (1977) and Pomeroy (1974) all proposed that professionals from the general recreation and parks should be trained and provide community-based recreation services for people with special needs. Volunteers are more than an asset to your organization. They are essential. However, we need to provide appropriate training and coordinate assignments for them. The use of volunteers fosters the spirit of community building. Again, volunteers must be fully briefed about the mission and expectations of the organization and properly trained to serve the participants with handicaps. Continuing education departments of universities can provide most invaluable in-service training programs both for your staff and volunteers. While KLRA also offers certification and accreditation to training programs on various areas of specialization including courses for leadership in recreation including the area on "Recreation for the Handicapped and the Elderly", it appears that the program and curriculum need to be expanded. Perhaps, the KLRA can work with some institution such as the University of Oregon in expanding this leadership program.

\section{An Effective Working Committee/ Board}

Whilst a honorary group of select personnel or dignitaries can bring professional advice and financial resources as well as political influences to an agency, it must be remembered, as discussed before, that, to be effective and organization must have an active executive committee or board comprising dedicated members who constantly contribute ideas and help toward the planning and implementing of activities, and at the same time, finding resources and managing the entire organization at their appropriate levels.

\section{Political Sensitivity / Awareness and Tactfulness}

The top executives and the executive committee members must be "politically" minded in order to capitalize on events that can result in obtaining resources for the agency. As examples, in Canada, the project, Bridging the Gap was conceived in response to the community's crying need to integrate the young and old and the socially underprivileged.

Let me illustrate with another example. After a serious riot, in an effort to combat youth crimes and troubles, the Government of Hong Kong decided to launch a comprehensive leisure and recreation program to "keep young people off the streets". The recreation professional hastened to take advantage of this political move, and subsequently countless youth and adults benefited from the direct services and impact of the leisure activities provided by a special appropriation of a handsome public fund. In fact, the current sophisticated leisure system of Hong Kong is the product of this special comprehensive program thanks to the sensitivity, prompt response and sustained efforts of recreation professionals along with continued support of the public authorities.

Tact needs to be exercised when we try to collaborate with other agencies in providing a joint program for persons with disabilities. So many worthwhile projects have been fouled by tactless approaches of top executives and key office-bearers of voluntary agencies purely because of petty jealousy between the personnel of the agencies. This characteristic is universal, and we must guard against it. On the other hand, synergy is crucial to successful programs in the present climate of economic stringency. 
Leaders should be able to meet the challenges of practical politics, and deal with political officials, legislators, or government departments in constructive and professionally sound ways to gain support for their agency (Kennedy et al, 1990).

Key officials must also be abreast of current legislation and laws applicable to the provision of leisure service programs for the handicapped. Oftentimes, the introduction of new legislation can mean an excellent opportunity for increase resources and awareness along with enhanced and improved services. For example, in the US, the Americans with Disabilities Act (ADA) put into effect in January, 1992 has a profound impact on increased opportunities for people with disabilities in the US (Ward, 1992). The ADA can well serve as a model internationally.

In conclusion, recreation leaders today are confronted with many obstacles to programming for people with special needs. These include insufficient budgets, inadequate facilities, architectural barriers, insufficient number of trained program personnel, transportation problems, the feelings that other community agencies already provide programs, and a lack of awareness of the need for programs for people with disabilities.

To overcome these problems and to develop an effective program in a community we need dynamic and skilled leadership. No one in Korea is more qualified and better positioned than you - members of the Korea Leisure and Recreation Association to further develop the program in your society, and to contribute toward the body of knowledge for the betterment of persons with disabilities in the world!

The world is rapidly changing. Naisbitt (1982) in his best-seller, Megatrends, reflects on the rapid changes in society when he states: "Change is occurring so rapidly that there is no time to react, instead we must anticipate the future" and Godbey (1989) echoed, " Recreation, park, and leisure service professionals will be challenged, first and foremost, to be actors rather than reactors in the change process".
Among the many essential attributes leisure and recreation professionals should have, is "a sense of humor" (Kennedy et al. 1991). Apart from hardwork and skills, we do need "a sense of humor" as we work through the tough process of providing increased opportunities of leisure and recreation for persons with disabilities!

* This paper was presented to the Members of Korea Leisure and Recreation Association in Seoul, Korea in 1997.

\section{Reference}

Godbey, G. (1989). The Future of Leisure Services : Thriving on Change. PA : Venture..

Kennedy, D., Smith, R. \& Austin, D. (1991). Special Recreation: Opportunities for Persons with Disabilities. IA : Wm. C. Brown Publishers.

Kim, O. (1988). Prospects for Leisure in Korea Vis-a-vis Opening of the Seoul Olympic Games. Unpublished paper presented at the University of Oregon.

MacKenzie, R.A. (1990). Teamwork through Time Management. Chicago : Dartnell.

Naisbitt, J. (1982). Megatrends : Ten New Directions Transforming Our Lives. N.Y. : Warner Books.

Pomeroy, J. (1974). One community's effort. Paper presented at the Institute on Community Recreation for Special Populations. Arlington, TX, July 19, 1974.

Stein, T. \& Sessoms, H. (1977). Recreation and Special Populations (2nd ed.). Boston : Holbrook.

Ward, H. (1992). The Common Law : The Americans with Disabilities Act Explained. Oak Ridger, Wednesday, July 1, 1992, p.10. 